\title{
Implementation Strategy of 9-Year Compulsory Basic Education Policy in Serang Banten
}

\author{
Lia Amalia ${ }^{1}$, Neti Karnati ${ }^{2}$, Nurhatatti Fuad ${ }^{3}$ \\ 1,2,3 Universitas Negeri Jakarta, Indonesia
}

Corresponding Author: Lia Amalia, $\otimes$ liaamalia_mp14s3@mahasiswa.unj.ac.id

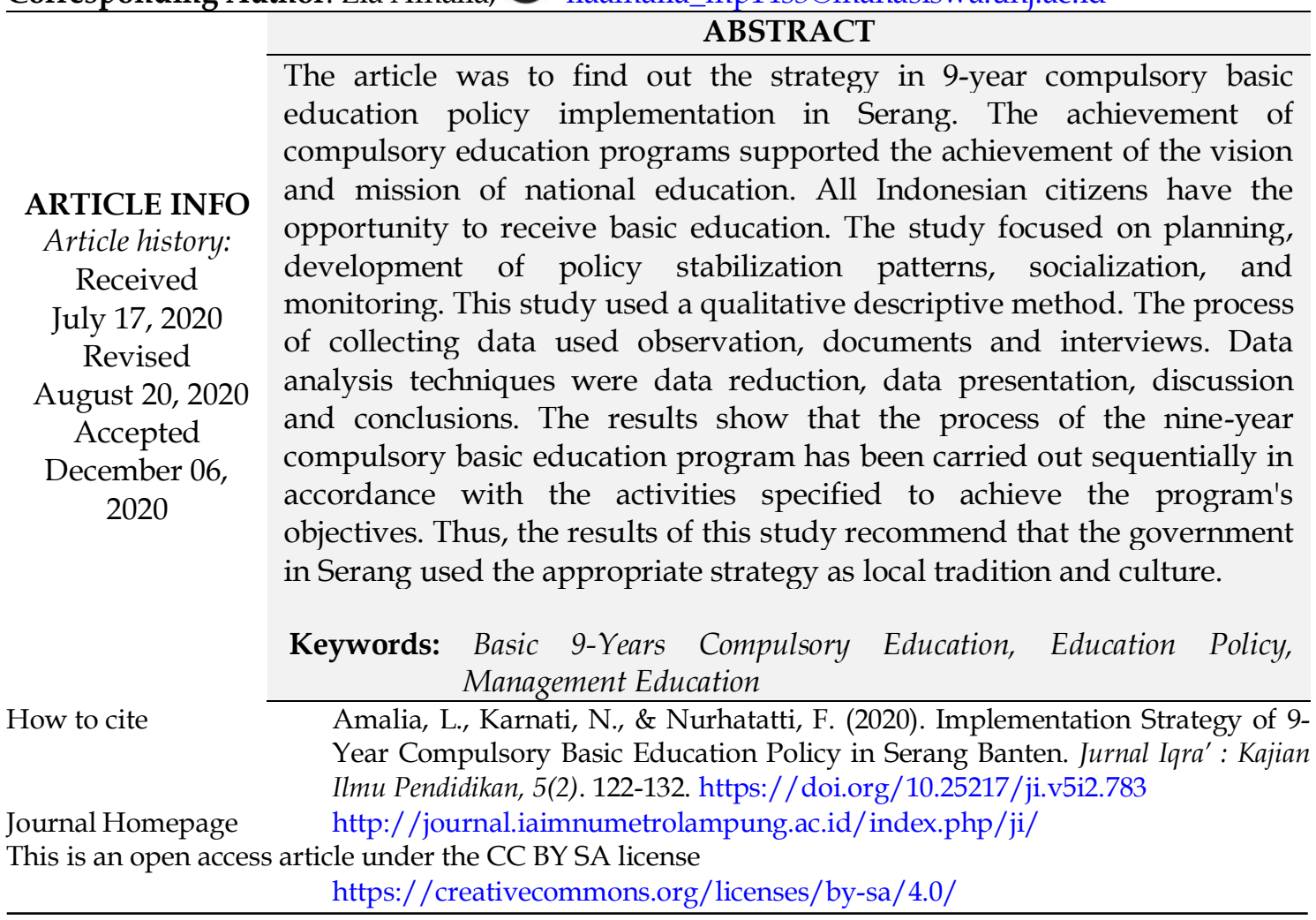

\section{INTRODUCTION}

The 9-year compulsory basic education is a main priority policy of the government since the 1970s. In 1983 began the 9-year compulsory basic education policy for children aged 7-12 years. This is in accordance with the mandate of Law Number 2 in 1989 concerning the National Education System. The 9-year compulsory basic education policy up to the secondary level is a standard for all citizens. The emergence of these policies due to various conditions that occur in the field, such as; 1) $80 \%$ of the workforce has only elementary school education, or junior high school has not graduated, 2) 9-year compulsory basic education policy will improve the quality of human resources and can also add the value economic growth, 3) the higher the education will be the greater the participation and contribution in productive sectors, 4) increasing the 9-year compulsory basic education policy will improve students' maturity and skills; 5) increasing the 9-year compulsory basic education policy will increase the minimum working age from 10 to 15 years. The 9-year compulsory basic education policy has been outlined in Government Regulation Number 47/2008.

Government Regulation No. 47/2008 describes the 9-year compulsory basic education policy objectives of the civil service, namely providing minimal education for Indonesian citizens to develop their potential to be able to live independently in 
society or continue their education to a higher level (Pemerintah Republik Indonesia, 2008). To achieve this goal, the implementation of the 9-year compulsory basic education policy program must have the right strategy. This strategy covers the planning process to the socialization of the 9-year compulsory basic education policy.

It is known that the implementation of the 9-year compulsory basic education policy in Serang has not reached the ideal conditions as expected from the government to improve the quality of Indonesian citizens as in Regulation number 20/2003 concerning the National Education System and Regulation Number 47/2008. The success of the 9-year compulsory basic education policy implementation was marked by the success of education programs, implementation of the elementary school curriculum, student learning outcomes, and budget realization. These four aspects should have shown the success rate of good quality human resources which is marked by the level of community welfare. Problems that are summarized from the implementation of the 9-year basic education service policy are: (1) it has not been increasing the awareness of some community members about the importance of education, (2) the high dropout rates at the primary and secondary school levels while the numbers continue to secondary school are still not maximized and, (3) the gross enrollment rate and pure participation rate are still not optimal at the secondary school level.

A study of the successful implementation of the 9-year compulsory basic education policy has not been carried out. This happens because the key to the successful implementation of a policy is on the evaluation of the implementation of the intended policy, to find out what extent the implementation of the 9-year compulsory basic education policy has been achieved, what are the obstacles faced and how is the solution. Thus, it needs a research that refers to evaluate of the 9-year compulsory basic education policy.

Several studies have been carried out relating to the evaluation of educational policies such as the 9-year basic education policy. Anti (2015) found the factors that influence the 9-year compulsory basic education policy in the new week in 2012 are standards and objectives, communication, characteristics of implementing agencies, social and economic conditions and dispositions. This research only discusses basic knowledge from the context of the goal and it is not the overall policy context. Mugiri \& Lestari (2013) concluded that evaluation activities such as School Operational Costs Funds in Pekalongan should have standard instruments. This is different from the evaluation of School Operational Costs Funds in Mamuju Regency. The evaluation results show that the use of School Operational Costs Funds is quite good although there are still weaknesses and strengths (Akbar, 2016).

The formulation of non-formal education in this study is an educational process that not only equips residents to learn with a number of abilities (knowledge, attitudes, etc.) but also prepares their learning citizens to become human resources capable of actualizing their potential in society (Rahmat, 2013). Zhang et al. (2011) have explained that the CIPP evaluation model provides a systematic guidance framework for the conception, implementation and assessment of service-based learning projects for teacher education. Stufflebeam CIPP evaluation model has been used and designed not only to prove a decision but acts as a fixer where the information can be used as a guide for designing a program (Hasan, Yasin, \& Yunus, 2015). There are many models of evaluation that can be used to evaluate a program. Stufflebeam and Shinkfield suggest product evaluation conducted for the four aspects of evaluation: impact, effectiveness, sustainability, and transportability (Warju, 2016). Program design has 
many obstacles. The biggest obstacle is found in the process and product variables related to the evaluation of non-academic learning achievement (Darma, 2019).

From the previous research, it has oriented to the evaluation of an educational program. They evaluated a program using CIPP to know the effectiveness of learning, education process and product or impact of program. However, this study focused to explored the strategy in evaluating the strategy of the 9-year compulsory basic education policy in Serang. It is a compulsory program that had impact to increase human quality in Serang. This study is important to conduct for several reasons, namely 1) the strategy used is in accordance with the needs in implementing the 9-year compulsory basic education policy, 2) the compulsory education program should be able to make a major contribution to changes in people's lives in Serang City, 3) evaluation compulsory education program requires periodic evaluations that must be understood from a perspective other than the organizer such as the Serang City Education Office. Therefore, this study aims to examine more deeply about the strategy of implementing the 9-year compulsory basic education policy program in Serang City to determine the success of the compulsory education program.

Thus, the results of this study are expected to be one of the contributors to the improvement of the implementation of the 9-year compulsory basic education policy program in Serang City. The evaluation can be a reference for improvement in parts of the compulsory education program that have not been implemented. Whereas in this study, the study focused on analyzing the implementation strategy of the 9-year compulsory basic education policy program. Thus, the purpose of this study is to find the strategy of the 9-year compulsory basic education policy implementation

\section{METHOD}

The study used a qualitative descriptive method. Ary, Jacobs, Sorensen, \& Razavieh (2010) stated that qualitative research did to comprehend the phenomenon using human being perspective as naturally. It means that this study used a qualitative descriptive method to explore the strategy in implementing of 9-year compulsory education policy in Serang Banten. It evaluates the process of implementing of 9-year compulsory education policy. The research describes the tendency of symbolic phenomena and reflects what they are from field data and document findings. The research procedure consisted of three stages in qualitative research, namely 1) prefield, 2) field activities and 3) intensive analysis (J.Moleong, 2007). The process of collecting data used the observation, interview, and documentation. Interview conducted on sources of information (informants). The informants are Head of Banten Province Education Office, Head of the Serang City Education Office, Head of the Education Office Branch Kasemen District, and Head of the District Education Office Branch in Cipocok. Observations conducted researchers to visit the research location in order to know the actual conditions related to information/data collected. Documentation used to analyze and to collect data from the documents concerning the implementation of the 9-year compulsory basic education policy in Serang, including archival documents in the form of rules, legislation, decrees, planned activities, photos of activities, reports and so on. The data analysis technique in this study was carried out with a qualitative data analysis technique that began by examining all data collected from various sources, namely interviews, observations, and documents. Analysis of the data used the stages of data reduction, data presentation, discussion and drawing conclusions. 


\section{RESULT AND DISCUSSION}

Implementation of the 9-year compulsory basic education policy in Serang used the appropriate strategy which is relevant to the Government Regulation Number. 47 of 2008. Here is the finding of the strategy of 9-year compulsory basic education policy implementation.

Table 1. The strategy of 9-year compulsory basic education policy implementation

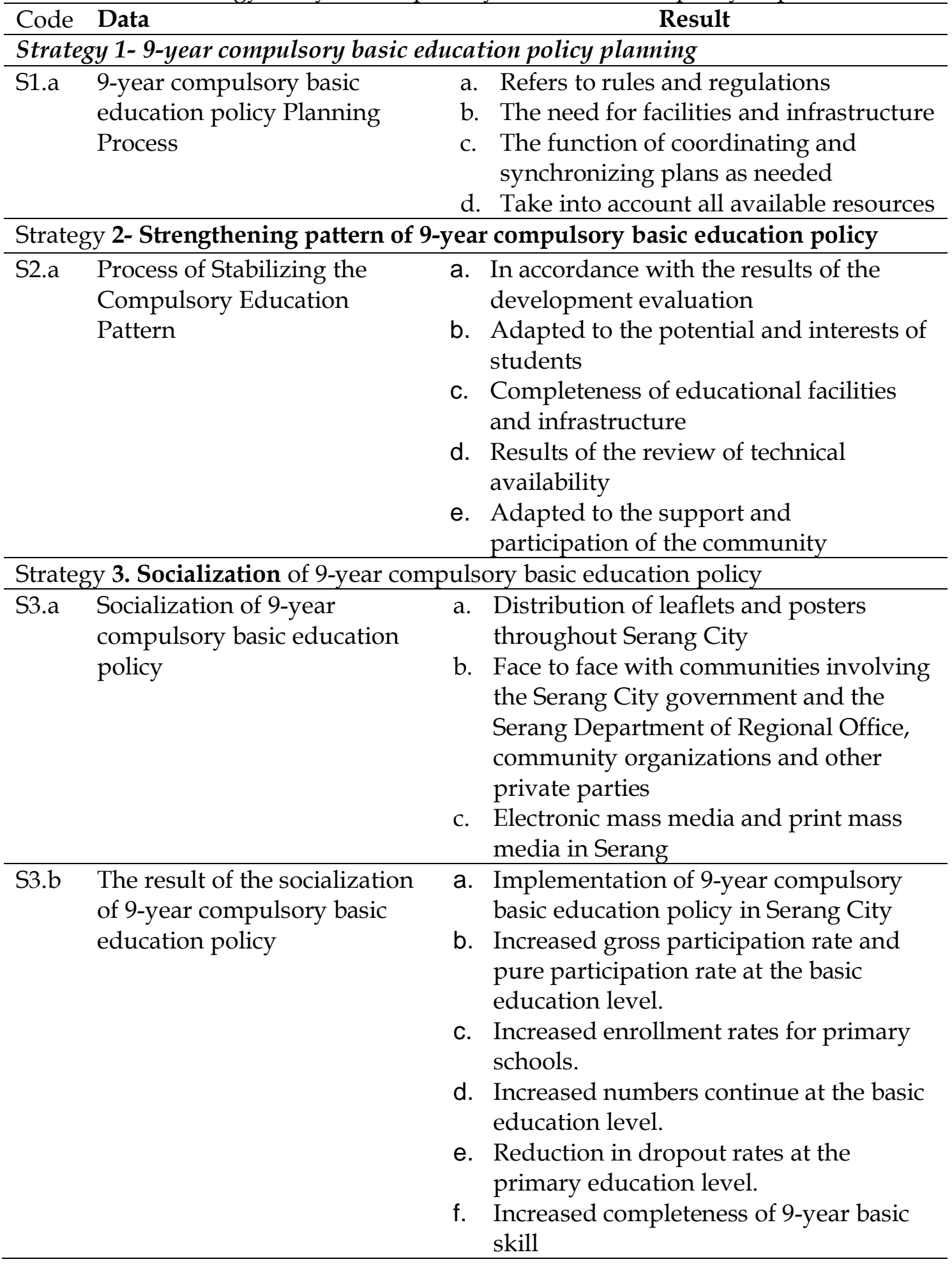




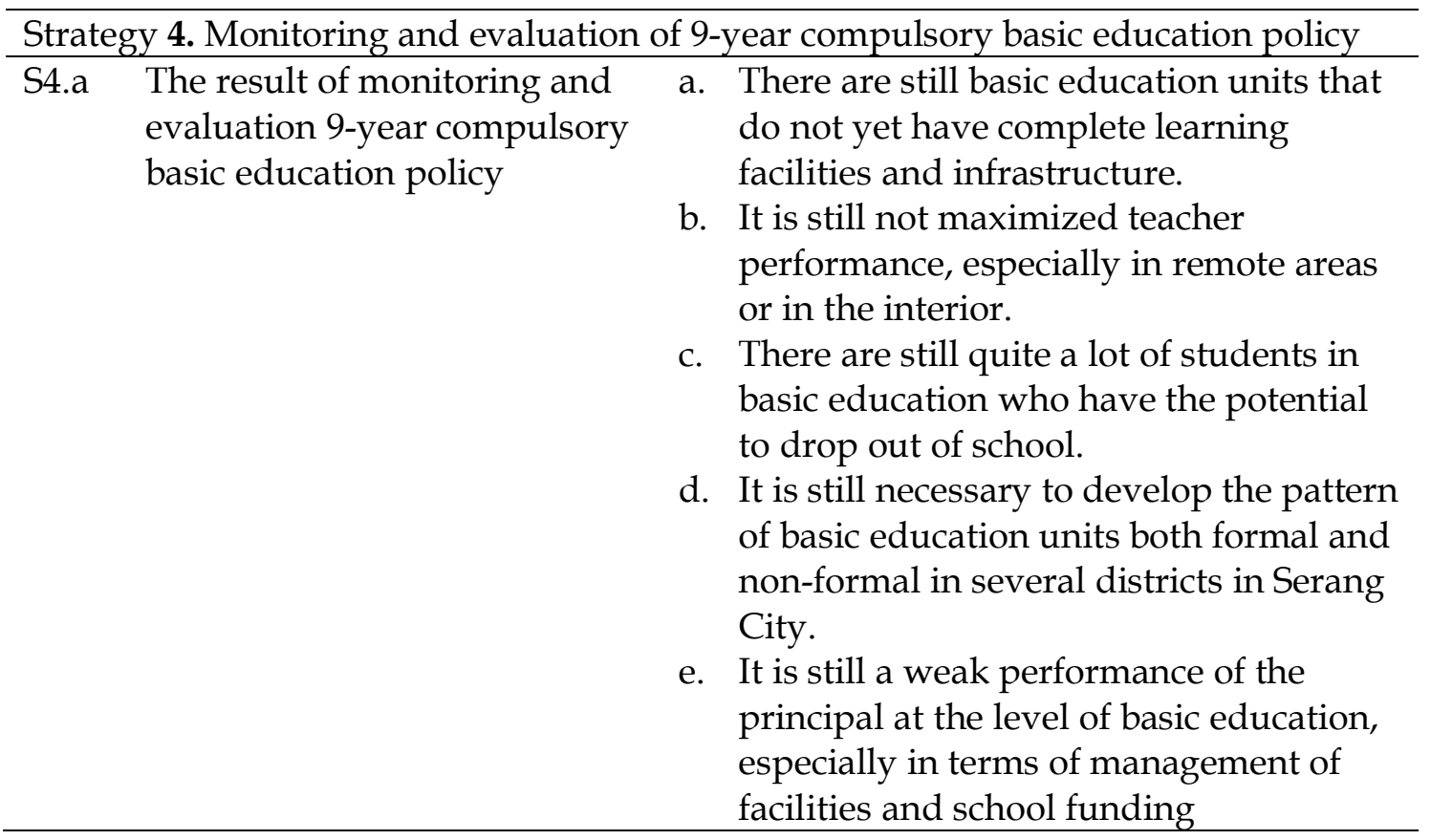

The urgency of 9-years compulsory basic education policy planning in the context in Banten Provincial Education Office is more likely to consider the following matters:

a. Good planning should be oriented to concern to the rules and regulations that apply in the 9-year compulsory basic education policy to ensure the legality of the action to be taken.

b. Good planning must be done through a systematic, synergistic and coordinating process so that the determination of priority goals to be achieved can be more realistic and precise.

c. Good planning must take into account the internal strengths of compulsory and logical 9-year compulsory basic education which is effective and logical to minimize the mistakes that occur.

d. Effective planning must also be supported by information, data and document materials that are valid, accurate and complete so that decision making in planning will be more appropriate.

e. Good planning should also be reflected in past experience in implementing the 9year compulsory basic education policy so that it does not repeat the same mistakes, this is important to consider because the limited resources available must be used as efficiently as possible.

f. Good planning must also consider the current conditions and situations that develop in the community because this greatly influences the implementation of the plan to be carried out, taking into account those situations and conditions will be able to formulate a plan that is more realistic and focused on achieving the objectives of 9-years compulsory basic education policy is more precise and effective to achieve maximum results.

g. Effective planning must have a complete plan control pattern in the form of monitoring and evaluation of the results obtained, identifying obstacles and factors supporting the plan and some of them, so that they can be useful input or feedback at the next planning stage. 
It is known that many factors affect the planning strategy in implementing of 9years compulsory basic education policy. A different opinion was conveyed by Head of Serang City Education Office that one of the bases for determining the provision of facilities and infrastructure in the framework of 9-years compulsory basic education in Serang City was compiled from the results of school data collection and mapping as well as proposals or input from schools at the level of primary education which urgently needed facilities and infrastructure education is meant, then the provision of basic education facilities and infrastructure in Serang City is very important to be followed up and implemented. Therefore, the teaching and learning process in schools can run well in order to support the completion of the planned 9-years compulsory basic education policy. Good planning management according to the Head of the Kasemen Subdistrict Education Office Branch is to prioritize information and data obtained from feedback to improve the performance of the plan more optimally, but it is also important to pay attention to plan more realistically according to ability and sources, resources owned. The implementation of the 9-year compulsory basic education policy is to be planned by the Banten Provincial Education Office, in general, can run well, although there are still some technical obstacles encountered in its implementation, however, there is quite a lot of feedback from the benefits obtained to improve the 9-years compulsory basic education policy plan.

The results of the analysis conducted on the interview data with Head of the Serang District Kasemen District Education Office Branch obtained the conclusion that the successful implementation of the 9-year compulsory basic education policy is known from;

a. Achieving more targeted policy/activities.

b. The results of policies/activities have further improved the quality of education

c. The implementation of the 9-year compulsory basic education policy is better.

d. Improvements in the field of knowledge, skills, attitudes and morals of students for the better.

e. Improving the quality of students facing the era of globalization

A review of the results of subsequent evaluations on the process and implementation of 9-year compulsory basic education policy in Serang City is reviewed from the aspect of strengthening the 9-year compulsory basic education policy pattern, this consolidation is viewed in terms of planning, management, implementation and the results achieved. In accordance with the results of an interview with the Head of the Serang City Education Office, it was found that the planning for strengthening the 9-year compulsory basic education policy pattern in Serang City was as follows:

1. The development and determination of the pattern of basic education that has been implemented

2. Refer and examine the results of monitoring and evaluation as supporting material in the analysis of the establishment of the 9-year compulsory basic education policy pattern

3. Paying attention to data on the potential and interests of children of primary school age who have not been accommodated by dropping out of school or children with special needs

4. Paying attention and calculating technical matters regarding the availability of tools, infrastructure and sources of funds and human resources.

The effectiveness of the 9-year compulsory basic education policy socialization carried out by the Serang City Education Office and its staff in the context of 
implementing and completing the 9-year compulsory basic education policy in Serang City which viewed in terms of preparation, management, implementation and the results achieved have been assessed as good. The results of an interview with the Head of the Serang City Education Office regarding the planning of the 9-year compulsory basic education policy concluded that the planning of the socialization of the implementation of 9-year compulsory basic education policy in Serang City was carried out by the Serang City Education Office through the Secretariat in the Planning Section which was adjusted to the Basic Education Policy. It has been determined and designed according to the needs of the Sub-district area which has the potential to develop 9-year compulsory basic education policy pattern, and has the potential of sufficient educational resources and refers to the existing rules.

It can be concluded that the planning for the socialization of 9-year compulsory basic education policy service in Serang City has been carried out well with a focus on sub-district areas that have the potential for development and sufficient resources and are carried out in accordance with applicable rules and regulations. The 9-year compulsory basic education policy seminar was carried out by the Education Office through a number of ways, namely distributing leaflets and posters throughout Serang City, face-to-face meetings with communities involving the Serang City government and the Serang City Department of Religion Office, community organizations and other private parties. The socialization was also carried out through electronic mass media and print mass media in Serang City. The implementation of the 9-year compulsory basic education policy socialization carried out has used a variety of methods that are quite effective, in addition to using face-to-face, the socialization is also carried out through various media both print and electronic.

The research that has been carried out provides a detailed explanation of the weaknesses, strengths and challenges faced by the Indonesian government to implement the 9-year compulsory basic education policy. While in Turkey, the government has education program was compulsory for 11 years and the school system was formed as general middle education (Gelisli \& Beisenbayeva, 2015). In China, the distance between the school and the house is also a major factor in the cost of education for the community (Cai, Chen, \& Zhu, 2017). This phenomenon is like what happened in Serang City. The process of compulsory education in China also affects on cognitive achievement and public health (Xiao, Li, \& Zhao, 2017). In Indonesia, the 9-year compulsory education has an impact on the quality of the individual which has an impact on the ability to work well. Another aspect that often becomes an obstacle in implementing compulsory education is funding. This often leads to inequality of learning outcomes (Gauthier \& Punyasavatsut, 2019).

The implementation of compulsory education in its development in Norway has a different impact with globalization. The provision of education does not pay attention to the special conditions of a village (Solstad \& Andrews, 2020). Education should provide equity for the needs of every society (Erten \& Keskin, 2019). Education should provide equity for the needs of every society. Education must also provide equal quality qualifications (Kabakçi, Kiliçer, Birinci, Şahin, \& Odabaşi, 2010). In other countries, the implementation of compulsory education policies has also been carried out to improve quality. Various efforts are used to change the education system. Reform of the education system that gives very good results for example in the country of Finland. In November 1968, parliament passed a law to create a new basic education system that was built based on the general model. The Basic Education Law was passed in 1968, introducing a new comprehensive school system and replacing 
existing two levels. Students will now enter comprehensive school at the age of nine and remain up to sixteen years. In total, there are nine classes, divided into six years of elementary school and three years of junior high school (Risku, 2014).This new system offers three academic levels in mathematics and foreign languages: elementary, intermediate and advanced. What is taught in civil schools relates to the elementary level, whereas those in grammar schools are equated with the advanced level (OECD, 2011).

The education system in Finland is carried out centrally. This has similar concepts with Indonesian government policies. However, currently the government has given authority to local governments to improvise the implementation of the 9year compulsory basic education policy. However, the policy system still refers to the center. The education system is carried out comprehensively (Kauko, 2019). Whereas in Indonesia, it is seen in the concept of curriculum that refers to holistic and comprehensive learning and teaching.

Education is an important element in increasing student awareness about the environment. Because education plays an important role in shaping and transforming society. Free and compulsory education for all children will strengthen human rights internationally, but do not shape a global education strategy (Ahmadi \& Laei, 2012). Therefore, teachers must make every effort to expand students' knowledge, skills and attitudes (and thus competencies) in this field. This must be implemented, e.g, it is by actively including key issues for sustainable development in the education program. sustainable management of natural resources is part of an educational program, but they do not always know how to actively involve students. However, many teachers, especially Polish language teachers, still do not apply this problem in their curriculum (Mróz, Ocetkiewicz, \& Tomaszewska, 2020).

The results of the different studies show that compulsory education in Romania is understood from the perspective of institutional efficiency and provides a comparative analysis between Romania and OECD countries. The main conclusions emphasizing the existing gap between Romania and OECD developed countries require major institutional reforms that focus on matching resources with specific needs, results focused policies, and managerial autonomy (Baciu, 2012). In Norway, it has connected the linkages of schools that are required for society with the context of the needs of local communities (Solstad \& Andrews, 2019). A set of largely educational public policies aimed at increasing access to post-compulsory education. This policy is mostly oriented towards equity (Calero, 2008).

This study has contribution in improvement of education quality for education program in Serang. It refers to the government that must be directed towards efforts to improve the quality of education and education services so that graduates at all levels of education in Serang City have competitive competitiveness compared to other urban areas. The community in Kota Serang can have the development of many quality programs for the implementation of the 9-year compulsory basic education policy. This can have an impact on the number of continuing education to a higher level. Thus, people in Serang can have at least the final high school level. In this connection, the efforts of direct secondary education graduates to become workers who are ready to compete in the labor market need to also receive attention even though the ratio of the number of high schools and vocational high schools in Serang is approaching an ideal, namely $52.89 \%$ high school and $47.11 \%$ vocational school. This means that in matters of education, policies to expand vocational education 
services must be expanded in order to more effectively create efforts to make a workforce that is ready for work.

This research has implications for the implementation of the 9-year compulsory basic education policy in Serang, namely: Planning and implementation of education can be carried out comprehensively by the Serang City government, such as involving all stakeholders in determining the program of the 9-year compulsory basic education policy. Serang City already has the characteristics of a vision and mission which has been designated as a City of Education and has Islamic studies. Therefore, the Serang City government can provide a curriculum design related to the social and cultural context of the Serang City area. The activities of the 9-year compulsory basic education policy can be adjusted to the needs of the growing community of Serang City. Moreover, the city of Serang also has natural and human resources that continue to grow. Serang City Government, which has collaborated with the community, should build a local community that can function as a control for the implementation of the 9-year compulsory basic education policy in the event of irregularities. The Government especially the education office must provide comprehensive managerial authority or autonomy to each school with a structured supervisory system from the 9-year compulsory basic education policy policy implementation program

\section{CONCLUSION}

Strategy in the 9-year compulsory basic education program planning in Serang compiled and implemented by the Banten Provincial Education Office and Serang Provincial Education Office has met the established evaluation criteria, which have been well and effectively. The strategy used refers to the management of resources owned to the maximum, the management of education or management in schools that are organized, and the budget system that has been adjusted to the needs of current education. Some factors considered for program planning are the rules, internal strengths, information and materials owned, current educational developments and global challenges. Availability of facilities and infrastructure, regular monitoring and evaluation systems, capabilities of the Education Office, budget allocation, and sustainable and beneficial activities. The dissemination of 9-year basic education service in Serang has fulfilled the established criteria and carried out as a whole either through mass media, electronic or directly. Strengthening the 9-year basic education pattern adjusted to the results of program evaluations that are carried out periodically, and the level of participation of all parties in the implementation of Education. This pattern is built in accordance with the interests of prospective students and the potential of resources owned by the region. The process of strengthening the pattern of the 9-year basic education service program is carried out in accordance with the setting of goals, targets, which are adjusted to the vision and mission of Education in Serang City. Monitoring and evaluation of the 9-year basic education pattern meet the established evaluation criteria, which are carried out properly and effectively.

\section{ACKNOWLEDGEMENT}

Thank you to all people that helped me to finish this research including Head of Banten Province Education Office, Head of the Serang City Education Office, Head of the Education Office Branch Kasemen District, and Head of the District Education Office Branch in Cipocok. 


\section{AUTHOR CONTRIBUTION STATEMENT}

LA (Lia Amalia) was the main author in this paper. NK and NF were the second and the third author that help the main author to finish this research. They have guided the main author.

\section{REFERENCES}

Ahmadi, A., \& Laei, S. (2012). Public Education: Compulsory and Free? A Paradox. Procedia - Social and Behavioral Sciences, 47, 868-873. https:/ / doi.org/10.1016/j.sbspro.2012.06.749

Akbar, M. F. (2016). Evaluasi Kebijakan Program Pemberian Dana Bantuan Operasional Sekolah. Jurnal Analisis Dan Pelayanan Publik, 2(1). https:// doi.org/10.31947/jakpp.v2i1.1521

Anti, A. (2015). Implementasi program wajib belajar 9 tahun di pekanbaru tahun 2012. Jom FISIP, 2(2). Google Scholar

Ary, D., Jacobs, L. C., Sorensen, C., \& Razavieh, A. (2010). Introduction to Research in Education (8 Edition). CA: Cengage Learning. Google Scholar

Baciu, L. (2012). An Analysis of the Romanian Compulsory Education from the Perspective of Institutional Efficiency. Procedia - Social and Behavioral Sciences, 46, 2056-2067. https:/ / doi.org/10.1016/J.SBSPRO.2012.05.428

Cai, W., Chen, G., \& Zhu, F. (2017). Has the compulsory school merger program reduced the welfare of rural residents in China? China Economic Review, 46, 123141. https:/ / doi.org/10.1016/j.chieco.2017.07.010

Calero, J. (2008). What happens after compulsory education? Problems of continuity and possible policies in the case of Spain. The Social Science Journal, 45(3), 440-456. https:// doi.org/10.1016/J.SOSCIJ.2008.07.002

Darma, I. K. (2019). The effectiveness of teaching program of CIPP evaluation model. International Research Journal of Engineering, IT E Scientific Research, 5(3), 1-13. https:// doi.org/10.21744/irjeis.v5n3.619

Erten, B., \& Keskin, P. (2019). Compulsory schooling for whom? The role of gender, poverty, and religiosity. Economics of Education Review, 72, 187-203. https://doi.org/10.1016/j.econedurev.2019.06.001

Gauthier, B., \& Punyasavatsut, C. (2019). Inequalities in Presence of a School Funding Formula: The 15-year Free Education Program in Thailand. International Journal of Educational Development, 102100. https://doi.org/10.1016/j.ijedudev.2019.102100

Gelisli, Y., \& Beisenbayeva, L. (2015). Comparison of 12-Year Comsulsory Education in Turkey and Kazakhsan. Procedia - Social and Behavioral Sciences, 197, 1827-1834. https://doi.org/10.1016/j.sbspro.2015.07.242

Hasan, A., Yasin, S. N. T. M., \& Yunus, M. F. M. (2015). A Conceptual Framework for Mechatronics Curriculum Using Stufflebeam CIPP Evaluation Model. Procedia Social and Behavioral Sciences, 195, 844-849. https://doi.org/10.1016/J.SBSPRO.2015.06.324

J.Moleong, L. (2007). Metodologi Penelitian Kualitatif. Bandung: PT. Remaja Rosdakarya. Google Scholar

Kabakçi, I., Kiliçer, K., Birinci, G., Şahin, M. C., \& Odabaşi, H. F. (2010). A new step in Turkish Higher Education System: Program outcomes. In Procedia - Social and Behavioral Sciences (Vol. 9, pp. 76-80). Elsevier. https://doi.org/10.1016/j.sbspro.2010.12.118 
Kauko, J. (2019). The Finnish Comprehensive School. In Great Policy Successes (pp. 122142). Oxford University Press. https://doi.org/10.1093/oso/9780198843719.003.0007

Mróz, A., Ocetkiewicz, I., \& Tomaszewska, B. (2020). What should be included in education programmes - The socio-education analysis for sustainable management of natural resources. Journal of Cleaner Production, 250, 119556. https:/ / doi.org/10.1016/J.JCLEPRO.2019.119556

Mugiri, \& Lestari, W. (2013). Instrumen evaluasi program dana bos model cipP. Journal of Educational Research and Evaluation, 2(1). Google Scholar

OECD. (2011). Finland: Slow and Steady Reform for Consistently High Results. Strong Performers and Successful Reformers in Education: Lessons from PISA for the United States. Retrieved from https://www.oecd.org/pisa/pisaproducts/46581035.pdf. Google Scholar

Pemerintah Republik Indonesia. (2008). PP Nomor 47 Tahun 2008 tentang Wajib Belajar. PP Nomor 47 Tahun 2008 Tentang Wajib Belajar, 1-12. https:// doi.org/10.1017/CBO9781107415324.004

Rahmat, A. (2013). Evaluasi program pendidikan kesetaraan paket b. jurnal ilmiah visi p2tk paudni, 8(2). https://doi.org/10.21009/JIV.0802.6

Risku, M. (2014). A Historical Insight on Finnish Education Policy from 1944 to 2011. Italian Journal of Sociology Of, (June). https:// doi.org/10.21009/JIV.0802.6

Solstad, K. J., \& Andrews, T. (2019). From rural to urban to rural to global: 300 years of compulsory schooling in rural Norway. Journal of Rural Studies. https://doi.org/10.1016/J.JRURSTUD.2019.10.034

Solstad, K. J., \& Andrews, T. (2020). From rural to urban to rural to global: 300 years of compulsory schooling in rural Norway. Journal of Rural Studies, 74, 294-303. https://doi.org/10.1016/j.jrurstud.2019.10.034

Warju, W. (2016). Educational Program Evaluation using CIPP Model. Innovation of $\begin{array}{lll}\text { Vocational Technology 12(1). } & \text { Education, }\end{array}$ https:// doi.org/10.17509/invotec.v12i1.4502

Xiao, Y., Li, L., \& Zhao, L. (2017). Education on the cheap: The long-run effects of a free compulsory education reform in rural china. Journal of Comparative Economics, 45(3), 544-562. https://doi.org/10.1016/j.jce.2017.07.003

Zhang, G., Zeller, N., Griffith, R., Metcalf, D., Williams, J., Shea, C., \& Misulis, K. (2011). Using the Context, Input, Process, and Product Evaluation Model (CIPP) as a Comprehensive Framework to Guide the Planning, Implementation, and Assessment of Service-learning Programs. Journal of Higher Education Outreach and Engagement, 15(4), 57-84. Google Scholar

\section{Copyright Holder :}

(c) Amalia, L., Karnati, N., \& Nurhatatti, F. (2020).

First Publication Right :

(C) Jurnal Iqra' : Kajian Ilmu Pendidikan

This article is under:

()(1) (2) 